\title{
Detection and Diagnosis of Xylella fastidiosa by Specific Monoclonal Antibodies
}

\author{
María Teresa Gorris ${ }^{1}$, Antonio Sanz ${ }^{2}$, Javier Peñalver ${ }^{1}$, María M. López ${ }^{1}$, Mario Colomer ${ }^{3}$ \\ and Ester Marco-Noales $1, *$ (D)
}

1 Centro de Protección Vegetal y Biotecnología, Instituto Valenciano de Investigaciones Agrarias (IVIA), CV-315 km 10.7, 46113 Moncada, Valencia, Spain; gorris_mar@gva.es (M.T.G.); jpenal@ivia.es (J.P.); lopez_margon@gva.es (M.M.L.)

2 INGENASA, Hermanos García Noblejas 39, 28037 Madrid, Spain; asanz@ingenasa.com

3 PLANT PRINT Diagnòstics SL, Mayor 25, 46610 Guadassuar, Valencia, Spain; plantprint@plantprint.net

* Correspondence: marco_est@gva.es

Citation: Gorris, M.T.; Sanz, A.; Peñalver, J.; López, M.M.; Colomer, M.; Marco-Noales, E. Detection and Diagnosis of Xylella fastidiosa by Specific Monoclonal Antibodies. Agronomy 2021, 11, 48. https:// doi.org/10.3390/agronomy11010048

Received: 24 November 2020 Accepted: 22 December 2020 Published: 28 December 2020

Publisher's Note: MDPI stays neutral with regard to jurisdictional claims in published maps and institutional affiliations.

Copyright: () 2020 by the authors. Licensee MDPI, Basel, Switzerland. This article is an open access article distributed under the terms and conditions of the Creative Commons Attribution (CC BY) license (https: / / creativecommons.org/ licenses/by/4.0/).

\begin{abstract}
Monoclonal antibodies (MAb) specific to Xylella fastidiosa were obtained through hybridoma technology using heat-treated somatic O antigens from LMG 17159strain. Ten stable hybrydoma clones secreting MAb were selected and their isotype was determined. The MAbs 2G1/PPD, IgG showed specificity for X. fastidiosa, detecting all the analyzed strains representing different subspecies, STs and hosts. Polyclonal antibodies $(\mathrm{PAb})$ against $X$. fastidiosa were also produced and antiserum 17159-O/IVIA was selected for the highest titre and its excellent detection capability. MAb 2G1/PPD was tested against strain IVIA 5235 in PBS and in spiked raw extract samples from almond, olive, citrus, and other hosts and its sensitivity by DAS-ELISA was $10^{4} \mathrm{CFU} \mathrm{mL} \mathrm{m}^{-1}$. The MAb also reacted with high affinity and avidity against $X$. fastidiosa by DASI-ELISA and Tissue print-ELISA. The diagnostic parameters of DAS-ELISA based on MAb were calculated and compared with the gold standard real-time PCR. The diagnostic specificity of MAb2G1/PPD was 100\%, the diagnostic sensitivity was $88.5 \%$ compared to Harper's real-time PCR and $89.9 \%$ compared to Francis' real-time PCR. The agreement between the techniques was almost perfect according to the estimated Cohen's kappa-index, even in symptomless almond trees. The developed immunological techniques represent sustainable and low-cost analysis tools, based on specific, homogeneous, and well-characterized MAbs, which can be obtained in unlimited quantities in a reproducible way and constitute a guarantee for the standardization of commercial kits. They are a valuable option within a polyphasic strategy for the detection of X. fastidiosa.
\end{abstract}

Keywords: DAS-ELISA; DASI-ELISA; tissue print-ELISA; diagnostic parameters; Cohen's kappa index; sustainable diagnosis

\section{Introduction}

Xylella fastidiosa is one of the fifteen quarantine bacteria of highest phytopathological interest in the European Union (EU) [1]. It causes damaging diseases in strategic crops of socio-economic importance, and in ornamental and wild plants of a wide variety of botanical species [2]; the overall number of host plants in the last update by EFSA reached 595 plant species, 275 genera, and 85 families [2]. This pathogen is disseminated over long distances by the uncontrolled movement of infected, but frequently symptomless, plant material, and it is naturally transmitted by different species of insect vectors that spread the bacterium locally in a persistent and efficient manner [3-6].

$X$. fastidiosa is currently present in several European countries, mainly in Italy, France, and Spain [7], where a number of areas are under eradication or containment strategies in order to avoid dissemination of this quarantine organism [8]. The impact of the diseases caused by $X$. fastidiosa is very high, both in terms of production losses and the number of hectares affected [4]. In fact, in the Mediterranean area there are strategic crops for the 
various national economies, such as olive and almond trees, and even very important forest species, which have been threatened in the outbreaks reported in southern Italy, France, and Spain (Balearic Islands and Alicante) [4]. Consequently, the situation is also of great concern to international organizations such as the European and Mediterranean Plant Protection Organization (EPPO), the International Plant Protection Convention of the Food and Agriculture Organization (IPPC-FAO), and the European Food Security Agency (EFSA), which coordinate standards for diagnosis and detection of the pathogen [6,9], as well as guides for sampling [10] and an updated host list that is regularly revised due to the continuous increase of new host species [2].

The use of accurate and gold standard methods and reagents for detection and diagnosis of X. fastidiosa is needful to contain the spread and to ensure the commercialization of Xylella-free plant material, in order to preserve crops and forests of economic and environmental importance in the EU and in many Xylella-free countries worldwide. The molecular amplification techniques currently available [6] are very useful and play a key role in the preventive control and management of the disease. Nevertheless, real-time PCR protocols involve a high cost per sample and have some inhibition challenges, especially in certain hosts, and risk of contamination [11]. In fact, the PCR inhibitors present in some host species may decrease the sensitivity of optimized protocols because they are not always removed during the extraction and purification of nucleic acids. X. fastidiosa pathosystems can be considered a case study in microbial diagnosis because their large host range advises the use of polyphasic methods for more accurate detection and diagnosis.

In this context, highly specific immunological or serological techniques could be very useful, because their sensitivity is not affected by these inhibitors and are sustainable for large-scale testing, as has been demonstrated in several diseases [12,13]. Thus, protocols based on these techniques - that are economical, accurate, reproducible, sensitive, fast, and user-friendly - complete the availability of methods to reliably detect X. fastidiosa. Moreover, they could be used in public and private laboratories, nurseries, etc., for effective elimination of infected plants, even with no symptoms but with latent infections. Immunological methods and tools based on specific, homogeneous, and well-characterized antibodies must be part of a polyphasic strategy for the detection of X. fastidiosa, as has already been demonstrated for other pathosystems, which allows a drastic increase in the number of samples analyzed [11,14].

According to the IPPC-FAO [11], a number of serological methods, all of them based on conventional polyclonal antibodies (PAbs), have been developed for the detection of $X$. fastidiosa, including ELISA [15], membrane entrapment immunofluorescence [16], dot immunobinding assay [17], western blotting [18], and indirect immunofluorescence [19]. More recently, tissue print-ELISA or direct tissue blot immunoassay (DTBIA) has been reported as an alternative for rapid screening of olive samples for X. fastidiosa in Italy [20]. Some of these methods are also recommended in the EPPO standard for diagnosis of the bacterium [6]. However, in general, the immunological detection methods are less used than in the past, partially due to the non-availability of homogeneous and well characterized specific antibodies for some pathogens. The main drawbacks associated to PAbs are: (i) the poor specificity, (ii) the lack of homogeneity among different batches, (iii) the strong dependence on the individual immunized animal, and (iv) that only a maximum of $10-15 \%$ of the antibodies developed act against the injected antigen. This poses a serious problem regarding the standardization of commercial lots of antisera of uncertain specificity and cross-reactivity $[12,13,21]$.

Monoclonal antibodies (MAbs) offer numerous advantages, such as specificity, since nearly $100 \%$ of immunoglobulins are identical with a predefined specificity, which significantly reduces the number of false positives and cross-reactions in the assays. This confers accuracy and reproducibility to the immunological tests, as a result of the selection and characterization of antibodies of high affinity, avidity, and homogeneity. In addition, MAbs can be obtained in unrestricted amounts in a reproducible manner, which is a safeguard for the standardization of commercial kits. The perpetuity of hybridoma cell lines through 
culture and freezer storage offers the advantage of the reproducibility of MAbs over time and in different laboratories [22]. MAbs for X. fastidiosa were reported long time ago by Garnier et al. [23], but they were not evaluated or characterized and are not available.

In summary, integrated protocols for the detection of bacteria are advised, which include the use of molecular and serological techniques as screening methods, followed by confirmation using techniques supported by different biological principles [24]. The choice of the most accurate and suitable detection method is crucial and should be related to the final purpose of the analysis, especially in areas with the presence of $X$. fastidiosa, where extensive surveys and testing are required. It would be very useful to be able to include in the flowchart for the diagnosis of X. fastidiosa of the EPPO standard [6] the use of immunological methods based on MAbs.

The purpose of this research was to develop a useful specific tool and immunological methods for the detection of X. fastidiosa in large-scale programs that meet the requirements of speed, simplicity, low price, and accuracy desirable in a diagnostic technique intended for this purpose. This work demonstrates that the selected MAb2G1/PPDis a very promising tool that can be used for an accurate detection of X. fastidiosa by DAS-ELISA, tissue printELISA or by other sustainable serological techniques in massive monitoring programs, essential for the development of appropriate integrated management approaches to prevent the spread and establishment of this quarantine pathogen into new areas in the EU members and other countries.

\section{Materials and Methods}

\subsection{Bacterial Strains and Growth Conditions}

The Xylella fastidiosa bacterial strains used in this study are listed in Table 1. Strain LMG 17159 was used as antigen to raise the monoclonal antibodies (MAbs). Strain IVIA5235and strain Xc161 (Streptococcus mutans) were used as a positive and negative control, respectively, in DAS-ELISA and DASI-ELISA tests.The other strains listed were tested for reactivity against the obtained MAbs. All X. fastidiosa strains were routinely grown on PD2 medium [25] and incubated at $26^{\circ} \mathrm{C}$ for at least 6 days. Strains belonging to other genera of plant pathogenic bacteria tested for specificity studies are shown in Table 2 , and they were grown on yeast peptone glucose agar (YPGA) medium [26] and incubated at $25^{\circ} \mathrm{C}$ for $48 \mathrm{~h}$.

\subsection{Plant Material}

For the comparative sensitivity tests, 233 field samples, with and without X. fastidiosa-suspicious symptoms, from woody plant species such as almond (Prunus dulcis), olive (Olea europaea), sweet orange (Citrus sinensis), oleander (Nerium oleander), lavender (Lavandula spp.), Prunus spp., fig tree (Ficus carica), grapevine (Vitis vinifera), bay leaf (Laurus nobilis), Calicotome sp., rosemary (Rosmarinus officinalis), Polygala myrtifolia, Cistus spp., Helychrisum spp., and Phagnalon spp. collected in different areas of Spain and received at the National Reference Laboratory of Phytopathogenic Bacteria (IVIA) of the Spanish Ministry of Agriculture, were analyzed for serological detection of X. fastidiosa. Plants of each analyzed species kept at IVIA greenhouse facilities were also used as a source of healthy control plant material.

\subsection{Production and Characterization of Monoclonal and Polyclonal Antibodies against X. fastidiosa}

For the production of MAbs, suspensions of heat-treated cells (somatic $\mathrm{O}$ antigen) of strain LMG 17159 in $10 \mathrm{mM}$ phosphate-buffered saline (PBS) at $10^{9} \mathrm{CFU} \mathrm{mL}{ }^{-1}\left(\mathrm{OD}_{600}=1.2\right)$ were used to prepare bacterial antigens. To obtain heat-treated cells, $1 \mathrm{~mL}$ aliquots of the suspensions were subjected to $100{ }^{\circ} \mathrm{C}$ for $10 \mathrm{~min}$ and kept frozen at $-20{ }^{\circ} \mathrm{C}$ until use. Production of hybrid cells secreting Mabs specific for X. fastidiosa was performed by fusion between a non-secreting mouse myeloma and spleen cells from X. fastidiosaimmunized mice. BALB/c mice were immunized by intraperitoneal injection of $0.1 \mathrm{~mL} \mathrm{X}$. fastidiosa preparation ( $20 \mu \mathrm{g}$ protein) emulsified in an equal volume of complete Freund's 
adjuvant (Difco). Mice were subsequently injected with the same amount of preparation in incomplete Freund's adjuvant 15 and 30 days later. For 3 days before fusion, mice were injected with a daily dose of $10 \mu \mathrm{g}$ X. fastidiosa. Hybridization was carried out by using the line X63-Ag8-653, according to Vela et al. [27]. Determination of MAb isotypes antibody purification were performed as [27].

Table 1. Strains of Xylella fastidiosa tested for reactivity with the monoclonal antibody 2G1/PPD and antiserum 17159-O/IVIA.

\begin{tabular}{|c|c|c|c|c|}
\hline Strain & Host & Geographical Origin & Subspecies & ST \\
\hline CoDiRo & Olive tree & Puglia (Italy) & pauca & 53 \\
\hline Conn Creek & Grapevine & Napa (CA, USA) & fastidiosa & 1 \\
\hline Fetzer & Grapevine & Napa (CA, USA) & fastidiosa & 4 \\
\hline Stag's Leap & Grapevine & Napa (CA, USA) & fastidiosa & - \\
\hline Temecula & Grapevine & Temecula (CA, USA) & fastidiosa & 1 \\
\hline LMG 17159 & Grapevine & Florida (USA) & fastidiosa & 2 \\
\hline LMG 15099 & Almond tree & California (USA) & fastidiosa & - \\
\hline IVIA 5235 & Cherry & Balearic Islands (Spain) & fastidiosa & 1 \\
\hline IVIA 5387 & Almond tree & Balearic Islands (Spain) & fastidiosa & 1 \\
\hline IVIA 5388 & Almond tree & Balearic Islands (Spain) & fastidiosa & 1 \\
\hline IVIA 5770 & Grapevine & Balearic Islands (Spain) & fastidiosa & 1 \\
\hline IVIA 5772 & Grapevine & Balearic Islands (Spain) & fastidiosa & 1 \\
\hline IVIA 5773 & Grapevine & Balearic Islands (Spain) & fastidiosa & 1 \\
\hline IVIA 6015 & Rhamnusalaternus & Balearic Islands (Spain) & fastidiosa & 1 \\
\hline IVIA 6035 & Calicotomespinosa & Balearic Islands (Spain) & fastidiosa & 1 \\
\hline CFBP 8430 & Polygala myrtifolia & PACA (France) & multiplex & 6 \\
\hline IVIA 5908 & Almond tree & $\begin{array}{l}\text { Valencian Community } \\
\text { (Spain) }\end{array}$ & multiplex & 6 \\
\hline IVIA 5946 & Almond tree & $\begin{array}{l}\text { Valencian Community } \\
\text { (Spain) }\end{array}$ & multiplex & 6 \\
\hline IVIA 5947 & Almond tree & $\begin{array}{l}\text { Valencian Community } \\
\text { (Spain) }\end{array}$ & multiplex & 6 \\
\hline CFBP 8072 & Coffeaarabica & Ecuador & pauca & - \\
\hline CFBP 8419 & Coffeaarabica & Costa Rica & sandyi & - \\
\hline
\end{tabular}

Table 2. Bacterial strains belonging to different genera and species present in plant hosts tested for specificity with monoclonal antibody 2G1/PPD.

\begin{tabular}{cccc}
\hline Bacterial Species & Strain & Host & Geographical Origin \\
\hline Agrobacterium tumefaciens & C58 & Cherry tree & USA \\
A. vitis & IVIA 339-26 & Vitis vinifera & Spain \\
Breneriaquercina & IVIA 2803-2 & Quercus sp. & Spain \\
Clavibactermichiganensis subsp. & IVIA 5153 & Solanum & Spain \\
michiganensis & lycopersicum & France \\
Erwiniaamylovora & CFBP 1430 & Crataegus & Spain \\
Xanthomonasarboricola pv. pruni & IVIA 3161-2 & Prunus dulcis & Argentina \\
X. arboricola pv. pruni & CFBP 5229 & Prunus spp. & Spain \\
X. arboricola pv. pruni & IVIA 3978-2 & Corylus avellana & France \\
X. arboricola pv. pruni & CFBP 5562 & P. persica & Australia \\
X. arboricola pv. pruni & DAR 56679 & P. armeniaca & Italy \\
X. arboricola pv. fragarie & CFBP 6771 & Fragaria sp. & Poland \\
X. arboricola pv. juglandis & RIPF XO4 & Juglans regia & Spain \\
X. arboricola pv. juglandis & IVIA 1317-1a & J. regia & Hungary \\
X. axonopodis pv. phaseoli & CECT 914 & Phaseolus vulgaris & Spain \\
X. campestris pv. campestris & IVIA 2734-2 & Brasica oleracea & Spain \\
Xanthomonas spp. & IVIA 3080 & Capsicum annuum & Spain \\
Pseudomonas syringae & IVIA 2627 & Pyrus comunis & Spain \\
P. syringae & IVIA 2141 & Olea sp. &
\end{tabular}


The production of six PAbs was done in Californian $x$ Neozelander rabbits using heattreated cells as previously described (somatic O antigen) of strains LMG17159, LMG 15099 and Conn Creeck in 10mM phosphate-buffered saline (PBS) at $10^{9} \mathrm{CFU} \mathrm{mL}^{-1}\left(\mathrm{OD}_{600}=1.2\right)$. The immunization started by an intramuscular injection of the antigen mixed with Freund's incomplete adjuvant, that was done every ten days followed by the same dose of 1 $\mathrm{mL} /$ injection, for a total of two months. Indirect ELISA evaluated the titer after the last booster immunizing injection by sensitizing polystyrene microplates (Polysorp; Nunc) with $100 \mu \mathrm{L}$ of the homologous antigen, according to the conventional standard [28]. The antisera were sterilized by filtration and stored at $-70{ }^{\circ} \mathrm{C}$. Immunoglobulins were purified from antiserum 17159-O.

\subsection{Ethics Statement}

The Balb/c mice and the rabbits used to produce the antibodies described here were housed and handled at INGENASA facilities in accordance with the European legislation regarding animal welfare in research at that moment [29]. At the end of the experiment, animals were kept alive according to the requirements [29] for their use in subsequent experiments, and they received appropriate care under the supervision of a competent specialist.

\subsection{Reactivity and Specificity}

\subsubsection{Double Antibody Sandwich Enzyme Linked Immunosorbent Assay (DAS-ELISA)}

DAS-ELISA with alkaline phosphatase system (DAS-ELISA MAb), according to EPPO protocol PM7/101 [28] with minor modifications, was used to determine the reactivity and specificity of the different generated MAbs. The reactivity was determined using 21 X. fastidiosa strains from different subspecies, STs and hosts isolated in six countries worldwide. In addition, strains representing other species from different bacterial genera also pathogenic to various plant hosts were included for the specificity assay. Polystyrene microplates (Polysorp F96; Nunc) were used. The wells were coated with $200 \mu \mathrm{L}$ of purified immunoglobulins at $2 \mu \mathrm{g} \mathrm{mL} \mathrm{m}^{-1}$, incubated for $4 \mathrm{~h}$ at $37^{\circ} \mathrm{C}$ and washed. Then, $200 \mu \mathrm{L}$ of each bacterial suspension were added (two wells per each sample), plates incubated for $16 \mathrm{~h}$ at $4^{\circ} \mathrm{C}$ and then washed. Alkaline phosphatase conjugated Ig was added, incubated for $4 \mathrm{~h}$ at $37^{\circ} \mathrm{C}$ and washed again. The $\mathrm{OD}_{405}$ readings (ELISA values) were made at 30, 60, and $90 \mathrm{~min}$ after substrate incubation at room temperature in a TitertekMultiskan (Flow) reader. Values greater than a twice those of the negative control were considered positive (values of the negative control minor than 0.100 were considered as 0.100 ). Strain IVIA 5235 and strain Xc161 were included as positive and negative controls, respectively.

\subsubsection{Double Antibody Sandwich Indirect Enzyme Linked Immunosorbent Assay (DASI-ELISA)}

DASI-ELISA was basically performed according to EPPO standard [28]. Polystyrene

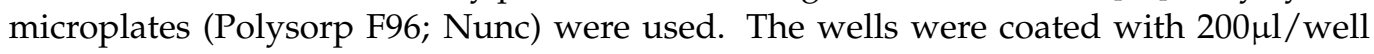
purified polyclonal immunoglobulins at $2 \mu \mathrm{g} / \mathrm{mL}$ in carbonate buffer as trapping/coating antibodies. Twenty $X$. fastidiosa strains were used to determine the reactivity and specificity. The intermediate Mab was used as detecting antibody and goat anti-mouse immunoglobulins alkaline phosphatase linked (Sigma, A-3562) were used as conjugate. The OD 405 readings (ELISA values) were made at 30,60, and 90 min after substrate incubation at room temperature in a TitertekMultiskan (Flow) reader. Values greater than a twice those of the negative control were considered positive (values of the negative control minor than 0.100 were considered as 0.100). Strain IVIA 5235 and strain Xc161 were included as positive and negative controls, respectively.

2.5.3. Direct Tissue Print-ELISA or Direct Tissue Blot Immunoassay (DTBIA) in Naturally Infected Samples

Twenty-eight samples collected from a commercial orchard of almond trees located at the demarcated area for X. fastidiosa in Alicante (Valencian Community, Spain), and 12 samples of olive trees from Ibiza (Balearic Islands, Spain), were analyzed by tissue 
print-ELISA as previously described [23,30]. Fresh cuts of petioles and shoots were pressed onto nitrocellulose membranes, covered with $1 \%$ solution of bovine serum albumin (BSA) with $1 \%$ ethanol and incubated overnight at $4{ }^{\circ} \mathrm{C}$ with a slight shaking. A solution of specific monoclonal antibodies against $X$. fastidiosa linked to alkaline phosphatase was added over the membranes, incubated for $4 \mathrm{~h}$ at room temperature and washed three times (washing buffer: PBS, pH 7.2-7.4 with $0.05 \%$ Tween 20 ) by shaking. Precipitating substrate for alkaline phosphatase (BCIP/NBT, Sigma Fast, Sigma) was added and incubated until a purple-violet color precipitates appears in the positive control. Prints of petioles of almond and olive trees maintained at IVIA greenhouse facilities were used as healthy controls, whereas prints of petioles of infected almond and olive trees previously tested positive by real-time PCR were used as positive controls. Membranes were observed under a binocular at low-power magnification (X10-X20). Presence of purple-violet color precipitates in the xylem area indicated the presence of $X$. fastidiosa.

\subsection{Sensitivity in DAS-ELISA and DASI-ELISA}

Sensitivity of MAb was determined by DAS-ELISA (MAb based), as described above, by using 10-fold serial dilutions of strain IVIA5235 in PBS at a range of concentrations from $10^{8}$ to $10 \mathrm{CFUmL}^{-1}$. Furthermore, sensitivity was also determined in spiked healthy plant material. To this end, $1 \mathrm{~g}$ of petioles of each host was macerated with $10 \mathrm{~mL}$ of extraction buffer (EB) (PBS pH $7.2+0.2 \%$ DIECA + 2\%PVP-10, sterilized by filtration) in sterile plastic bags (Bioreba), and then aliquots of $1 \mathrm{~mL}$ of extracts were spiked with strain IVIA5235 at $10^{8}$ to $10 \mathrm{CFUmL}^{-1}$ concentrations and frozen at $-20{ }^{\circ} \mathrm{C}$ until use. The same antigen dilutions were used by DASI-ELISA to estimate the sensitivity in serial dilutions of almond and olive tree spiked crude plant extract samples. Spiked olive and almond plant material was also used to compare sensitivity of the new DAS-ELISA using MAb with the DAS-ELISA based on PAb antibodies commercially available (Loewe Biochemica, Germany. Catalog number 07119S/1000).

\subsection{Detection of X. fastidiosaby DAS-ELISA Mab in Naturally Infected Samples}

Almond and olive tree plant samples from commercial orchards in the Demarcated Area for X. fastidiosa in Alicante (Spain), and the 233 samples described in Section 2.2. were processed according to EPPO diagnostic standard for X. fastidiosa [6] and analyzed by DAS-ELISA using the selected MAb.

\subsection{Comparison of DAS-ELISA MAb and Real-Time PCR for Detection of X. fastidiosa}

Aliquots from naturally infected plant samples processed as described above were analyzed in parallel by DAS-ELISA Mab and two standard protocols for real-time PCR according to EPPO [6]: Harper et al. [31] and Francis et al. [32], previous DNA extraction by CTAB method [6]. In order to compare the results of the different methods used, and evaluate the use of DAS-ELISA MAb as a new diagnostic tool, contingency tables were calculated. Diagnostic specificity, diagnostic sensitivity, false positive and negative ratings and relative accuracy were calculated according to Olmos et al. [33] and EPPO standard [6]. The agreement between techniques was evaluated using Cohen's kappa index [34], which indicates the proportion of agreement beyond that expected by chance. The benchmarks of Landis and Koch [35] were used to categorize Cohen's kappa index, where $<0.00$ is poor agreement, 0 to 0.2 is slight agreement, 0.21 to 0.40 is fair agreement, 0.41 to 0.60 is moderate agreement, 0.61 to 0.80 is substantial agreement, and 0.81 to 1.00 is almost perfect agreement. All data were also subjected to the McNemar $\chi 2$ test [36] to detect bias effect, which affects Cohen's kappa index results [37]. 


\section{Results}

\subsection{Production of Monoclonal Antibodies (MAb) and Polyclonal Antibodies}

A total of 10 stable hybrydoma clones secreting MAb against $X$. fastidiosa with the highest titres in the screening by indirect-ELISA (I-ELISA) were selected.Isotypes were determined, resulting in four MAb being Ig $G_{1}$, five being $\operatorname{Ig} G_{2 b}$ and one being $\operatorname{Ig}_{2 a}$. Three $\mathrm{Mab}$, that is $2 \mathrm{G} 1 / \mathrm{PPD}$ (isotype $\left.\operatorname{IgG}_{1}\right), 1 \mathrm{C} 6 / \mathrm{PPD}\left(\operatorname{IgG}_{1}\right)$, and 9F7/PPD $\left(\operatorname{IgG}_{2}\right)$ were initially selected for their high affinity to react against the bacterial antigens, high avidity as well as wide reaction spectrum against different $X$. fastidiosa strains. Then, immunoglobulins of the three MAb were purified by affinity chromatography in columns, conjugated with alkaline phosphatase, and combinations of those three MAb tested by DAS-ELISA MAb. The highest affinity and avidity were obtained using MAb 2G1/PPD for both uses, as coating antibodies to sensitize plates and as conjugate. Therefore, a system of DAS-ELISA was developed using MAb 2G1/PPD, as well as a DASI-ELISA coating with purified polyclonal immunoglogulins from a selected antiserum (see above).

A total of six polyclonal antisera: 17159-O/IVIA, 17159-H/IVIA, 15099-O/IVIA, 15099-H/IVIA, CoC-O/IVIA, and CoC-H/IVIA were raised and their titer determined by indirect-ELISA, with values higher than 32,000 for all them. The antiserum 17159-O/IVIA was selected for the higher titre against the homologous strain and because it recognized all the X. fastidiosa strains challenged, exhibiting high ELISA values that suggested high avidity against the antigen. Purified immunoglobulins from this antiserum were used as coating/trapping antibodies in the developed DASI-ELISA.

\subsection{Reactivity in Several Techniques and Specificity}

The MAb 2G1/PPD reacted with all the X. fastidiosa strains tested, representative of isolates of the subspecies fastidiosa, pauca, multiplex, and sandyi from nine plant species and six countries, in both the DAS-ELISA and the DASI-ELISA. All other tested strains belonging to other genera, from different hosts and origins, gave negative result, so no cross-reactions were observed.

Also, MAb 2G1/PPD reacted specifically with all samples analyzed by tissue printELISA (or DBTIA). The 12 olive tree samples tested were positives for both tecniques: tissue print-ELISA MAb2G1/PPD and Harper's real-time PCR. Out of the 28 samples of almond tree tested, 20 were positive by tissue print-ELISA MAb2G1/PPD while 25 were positive by real-time PCR. Three samples were negative by the two assayed techniques. The diagnostic sensitivity resulted $87.5 \%$ compared to the gold standard Harper's real-time PCR. It is remarkable to note that the assay included field symptomatic and symptomless samples.

\subsection{Sensitivity}

The sensitivity of the DAS-ELISA using MAb 2G1/PPD with serial ten-fold dilutions of strain IVIA5235 in PBS, expressed as the lowest amount of pathogen detected, was $10^{4}$ $\mathrm{CFUmL}^{-1}$. The same limit was reached in spiked extracts from samples of almond, olive, citrus, oleander, lavender, and rosemary plants, while in blueberry was $10^{5} \mathrm{CFUmL}^{-1}$. When the sensitivity of the MAb 2G1/PPD obtained in DAS-ELISA was compared with the reaction of the commercial polyclonal antibodies from Loewe in almond and olive trees extracts, the same sensitivity of $10^{4} \mathrm{CFU} \mathrm{mL} \mathrm{m}^{-1}$ was obtained (Figure 1).

The DASI-ELISA using PAb from antiserum 17159-O/IVIA and MAb 2G1/PPD also reached a sensitivity of $10^{4} \mathrm{CFU}$ of $X$. fastidiosa per $\mathrm{mL}$ of almond and olive tree extracts. 


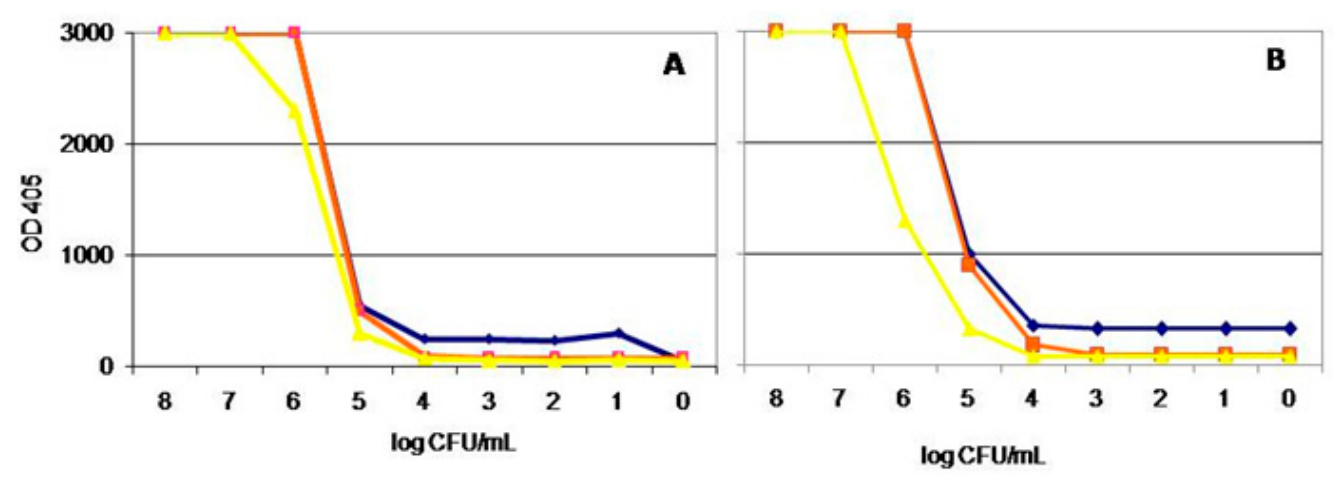

Figure 1. Sensitivity reached by MAb 2G1/PPD by DAS-ELISA (A) and by commercial polyclonal antibodies from Loewe (B) in almond (orange color) and olive (yellow color) tree extracts spiked with serial 10dilutions of the X. fastidiosa strain IVIA 5235. In blue color dilutions in PBS are represented.

3.4. Comparison of DAS-ELISA MAb with the Gold Standard Real-Time PCR for Detection of X. fastidiosa in Field Samples

A total of 165 field samples of almond, 40 of olive, 7 of Prunus spp., 5 of citrus, 3 of Calicotome sp., 3 of fig tree, 3 of rosemary, 2 of grapevine, and 1 of polygala, laurel, Cistus sp., Helychrisum sp., and Phagnalon sp., respectively, were analyzed by DAS-ELISA Mab2G1/PPD and real time PCR protocols [31,32] (Table 3). Out of the 233 total samples tested, 116 were positive by Mab2G1/PPD DAS-ELISA, while 131 were positive by Harper's real-time PCR, and 129 by Francis' real-time PCR. The number of negative samples by the three techniques was 102, so the diagnostic specificity of MAb2G1/PPD was $100 \%$, the diagnostic sensitivity $88.5 \%$ compared to Harper's real-time PCR and $89.9 \%$ compared to Francis' real-time PCR. No false positives results were obtained. Interestingly, the 15 samples that were negative by ELISA and positive by Harper's real-time PCR had an average $\mathrm{Cq}$ value of 30 . The relative accuracy obtained between techniques were $93.5 \%$ respect to Harper's and $94.4 \%$ respect to Francis'; these and other diagnostic parameters calculated are shown in Tables 4 and 5. The agreements between the DAS-ELISA Mab2G1/PPD and the Harper's and Francis'real-time PCRs were substantial and almost perfect, respectively, based on Kappa index of agreement of Cohen and McNemar test with a $p$-value $>0.001$ (Table 6).

Table 3. Analysis of plant samples for detection of Xylella fastidiosa by DAS-ELISA Mab 2G1/PPD, real-time PCR Harper et al. [31], and real-time PCR Francis et al. [32]. Positive samples by each technique/total samples analyzed.

\begin{tabular}{cccc}
\hline Host & $\begin{array}{c}\text { DAS- } \\
\text { ELISA;MAb2G1/PPD }\end{array}$ & $\begin{array}{c}\text { Real-Time } \\
\text { PCR;Harper et al. [31] }\end{array}$ & $\begin{array}{c}\text { Real-Time } \\
\text { PCR;Francis et al. [32] }\end{array}$ \\
\hline Almond tree & $150 / 165$ & $165 / 165$ & $163 / 165$ \\
Olive tree & $40 / 40$ & $40 / 40$ & $40 / 40$ \\
Prunus spp. & $7 / 7$ & $7 / 7$ & $7 / 7$ \\
Citrus tree & $5 / 5$ & $5 / 5$ & $5 / 5$ \\
Calicotome sp. & $3 / 3$ & $3 / 3$ & $3 / 3$ \\
Fig tree & $3 / 3$ & $3 / 3$ & $3 / 3$ \\
Rosemary & $3 / 3$ & $3 / 3$ & $3 / 3$ \\
Grapevine & $2 / 2$ & $2 / 2$ & $2 / 2$ \\
Polygala & $1 / 1$ & $1 / 1$ & $1 / 1$ \\
Laurus sp. & $1 / 1$ & $1 / 1$ & $1 / 1$ \\
Cistus sp. & $1 / 1$ & $1 / 1$ & $1 / 1$ \\
Helychrisum sp. & $1 / 1$ & $1 / 1$ & $1 / 1$ \\
Phagnalon sp. & $1 / 1$ & $1 / 1$ & $1 / 1$ \\
& $218 / 233$ & $233 / 233$ & $231 / 233$ \\
\hline
\end{tabular}


Table 4. Contingency table comparing mAb2G1/PPD DAS ELISA with real-time PCR Harper et al. [31] for Xylella fastidiosa detection in samples of naturally infected and healthy plants. The upper part shows the positive and negative results for each technique. The diagnostic parameters corresponding to these results are shown in the lower part.

\begin{tabular}{|c|c|c|c|c|}
\hline \multicolumn{5}{|c|}{ Harper's Real-Time PCR } \\
\hline \multirow{4}{*}{ DAS-ELISA } & & Positive & Negative & Total \\
\hline & Positive & 116 & 0 & 116 \\
\hline & Negative & 15 & 102 & 117 \\
\hline & Total & 131 & 102 & 233 \\
\hline & \multicolumn{3}{|c|}{ Diagnostic sensitivity } & $88.5 \%$ \\
\hline & \multicolumn{3}{|c|}{ Diagnostic specificity } & $100 \%$ \\
\hline & \multicolumn{3}{|c|}{ Positive predictive value } & $100 \%$ \\
\hline & \multicolumn{3}{|c|}{ Negative predictive value } & $87.1 \%$ \\
\hline Diagnostic parameters & \multicolumn{3}{|c|}{ False positive rate } & - \\
\hline & \multicolumn{3}{|c|}{ False negative rate } & $6.4 \%$ \\
\hline & \multicolumn{3}{|c|}{ Prevalence rate } & $56.2 \%$ \\
\hline & \multicolumn{3}{|c|}{ Likelihood ratio for positive results } & - \\
\hline & \multicolumn{3}{|c|}{ Likelihood ratio for negative results } & 0.115 \\
\hline & \multicolumn{3}{|c|}{ Relative accuracy } & $93.5 \%$ \\
\hline
\end{tabular}

Table 5. Contingency table comparing mAb2G1/PPD DAS ELISA with real-time PCR Francis et al. [32] for Xylella fastidiosa detection in samples of naturally infected and healthy plants. The upper part shows the positive and negative results for each technique. The diagnostic parameters corresponding to these results are shown in the lower part.

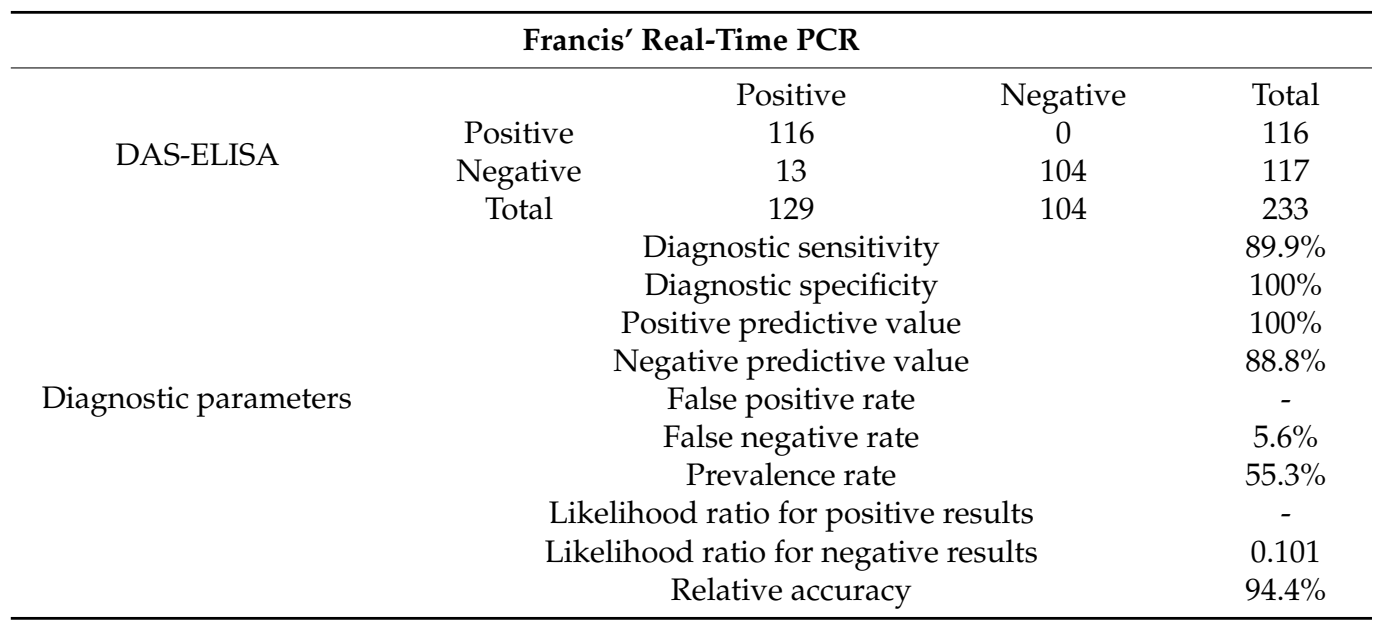

Table 6. Agreement between DAS-ELISA MAb2G1/PPD and real-time PCR by Harper et al. [31] or Francis et al. [32] for detection of X. fastidiosa in 233 tree samples from Demarcated Area for $X$. fastidiosa in Alicante (Spain).

\begin{tabular}{ccc}
\hline & $\begin{array}{c}\text { DAS-ELISA MAb2G1/PPD } \\
\text { vsHarper's Real-Time PCR }\end{array}$ & $\begin{array}{c}\text { DAS-ELISA MAb2G1/PPD } \\
\text { vsFrancis' Real-Time PCR }\end{array}$ \\
\hline $\begin{array}{c}\text { Agreement } \\
\text { Cohen's Kappa (95\% CI) }\end{array}$ & 0.93 & 0.94 \\
McNemar's test; $p$-value & $0.84(0.81-1.0)$ & $0.88(0.81-1.0)$ \\
\hline
\end{tabular}




\section{Discussion}

Immunological methods based on specific, homogeneous and well characterized antibodies are among the tools within a polyphasic strategy for the detection of X. fastidiosa. These methods can drastically increase the number of analyzed samples with good accuracy when based on specific MAbs $[9,11,14]$. The successful use of specific MAbs produced in this work by different direct and indirect serological techniques, such as DAS and DASI-ELISA, and tissue print-ELISA, show the ability of these antibodies to recognize $X$. fastidiosa. The intensity of the serological reaction suggests a high affinity and avidity of the selected MAbs to the antigenic determinants or detectable antigens of the target. These MAbs against X. fastidiosa, available for the first time, showed their usefulness and have been validated in this work as a reliable tool for the detection, identification, and diagnosis of this important phytopathogenic bacterium.

Interestingly, the selected MAbs, in particular 2G1/PPD (isotype $\operatorname{IgG}_{1}$ ), proved to be highly specific for X. fastidiosa, detecting all the strains analyzed representing different subspecies, STs and hosts. The high serological relationship observed by both DASIELISA and DAS-ELISA among the different $X$. fastidiosa strains tested, mainly with the MAb2G1/PPD, suggests that it recognizes a widespreadand well conserved X. fastidiosa epitope or antigenic determinant shared among the different strains. In the development of a rapid and large-scale diagnostic tool, species level recognition is the most suitable strategy, so that none of the variants that may be involved are left out, since co-infection of $X$. fastidiosa strains from different subspecies have been found in individual samples [38]. Furthermore, the MAbs obtained were highly specific because no cross reactions were observed against other phytopathogenic bacteria tested, not even with phylogenetically related strains of the genus Xanthomonas, nor with the usual microbiota of the host plants routinely analyzed.

When comparing the developed DAS-ELISA based on MAb2G1/PPD with the commercially available kit of Loewe based on polyclonal antibodies from antisera, both systems achieved the same sensitivity in both pure cultures and spiked samples, but the MAbs showed less background noise. In fact, leaf extracts of different plant species were tested and no significant differences in sensitivity were found between them, which demonstrates the general usefulness of DAS-ELISA MAb2G1/PPD for X. fastidiosa detection in a wide range of hosts, suggesting that there is not a remarkable influence of the plant material in its sensitivity. This may indicate that DAS-ELISA MAb2G1/PPD is not affected by the presence of potential inhibitors, like phenolic compounds, which is an advantage over molecular detection methodologies [26]. In the naturally infected samples analyzed, those that gave negative results by DAS-ELISA MAb2G1/PPD ( $\mathrm{n}=15$ respect to Harper's realtime PCR and $n=12$ respect to Francis' real-time PCR) belonged to different plant species, so no correlation was found between type of host and the negative result attributable to inhibition. What probably happens is that in trees with recent infections, the load of $X$. fastidiosa is very low, below the detection limit. Nevertheless, the overall capacity of DAS-ELISA MAb2G1/PPD for the detection of X. fastidiosa in different plant matrices can be considered excellent, since the pathogen was detected by the MAb in almond tree samples showing or not leaf scorch symptoms.

The sensitivity of $10^{4}-10^{5} \mathrm{CFU} \mathrm{\textrm {mL } ^ { - 1 }}$ is similar to that reported with other DASELISA for this pathogen [39] and better (one order of magnitude lower) than that of the commercially available DAS-ELISA from Agdia, as reported in an interesting comparison between serological and molecular methods [40]. The DAS-ELISA sensitivity of $10^{4} \mathrm{CFU}$ $\mathrm{mL}^{-1}$ is enough for $X$. fastidiosa detection not only in symptomatic samples from areas with high pathogen prevalence, but also in samples from areas with low presence of the pathogen, even if they remain asymptomatic for long periods. In fact, in the area of olive epidemics in Puglia (Italy), conventional PCR and ELISA proved to be equally effective, but ELISA was chosen for the large-scale monitoring programs in the demarcated area due to the simplicity of sample preparation that allows to process a higher number of samples [41]. Diagnostic specificity of the DAS-ELISA MAb 2G1/PPD was the same (100\%) 
when compared to both real-time PCR techniques, and diagnostic sensitivity was only slightly lower compared to Harper's real-time PCR $(88.5 \%)$ than to Francis' real-time PCR $(89.9 \%)$.

Naturally infected samples used in this study included different plant species and several plant tissues, i.e., leaves of different ages and, in some cases, wood. Remarkably, there were no false positives by DAS-ELISA MAb 2G1/PPD. This is particularly interesting because the occurrence of false positives in ELISA for the diagnosis of X. fastidiosa by polyclonal antibodies had been reported [19], not only in relation to the need to block non-specific binding sites [42], but also in relation to the potential activity of plant peroxidases [43]. It is also worth mentioning that some plant tissues did not seem more suitable than others for the detection of $X$. fastidiosa by DAS-ELISA MAb 2G1/PPD. This is important because, depending on the season, the use of one plant tissue or another may be more convenient [6], and this fact would not influence the detection efficiency by DAS-ELISA based on the produced MAbs, at least in almond and olive tree samples.

A comparison of the relative accuracy obtained between DAS-ELISA MAb2G1/PPD and the gold standard real-time PCR (93.5-94.4\%) demonstrates a strong correlation between the assayed techniques. In the analysis of almond tree samples from the demarcated area of Alicante (Spain), our results show a substantial or almost perfect agreement [35] between the DAS-ELISA MAb2G1/PPD and the two real-time protocols validated by EPPO [6]. This indicates the suitability of the serological techniques developed for $X$. fastidiosa diagnosis and detection. Cohen's kappa coefficient [34] constitutes a recognized method for evaluating agreement between two diagnostic techniques. This coefficient does not reveal which technique is better, but indicates how often they give the same results. In this work the detection results obtained by two different protocols of real-time PCR, considered gold standard, were compared with those obtained with the same field samples by DAS-ELISA based on the selected MAb 2G1/PPD. The agreement 0.94 was substantial with Harper's real-time PCR and it was 0.93, almost perfect, with Francis' real-time PCR, based on kappa index of agreement of Cohen and McNemar test with a highly significant $p$ value. The McNemar $\chi 2$ test indicated that bias was no significant, and Cohen's kappa index remained strong. In a recent work, Waliullahet al. [40] also found a high correlation between DAS-ELISA and real-time PCR for field and greenhouse collected blueberry samples infected with $X$. fastidiosa. It is known that the sensitivity of real-time PCR is better than that of ELISA, and this, together with the lack of expertise and equipment for serology in many laboratories of EU countries, has probably been the reason why this method has been excluded from the Implementing Regulation of the Commission (EU) 2020/1201 [8]. However, the results of this work show that serological techniques such as the ELISA developed with the MAbs, which has a high specificity, could be applied to the processing of a large number of samples. Thus, only those samples with negative results could be processed by real-time PCR to overcome false negative results by ELISA due to a low bacterial load.

To avoid the rapid increase of the pathogen population in a given crop, a consistent and early detection protocol is necessary, but, frequently, the use of a single method may not produce $100 \%$ diagnostic certainty. In international diagnostic standards it is advisable to use at least two tests based on different biological principles [6], particularly in areas apparently free of $X$. fastidiosa or those under containment strategy. The benefit of any detection technique depends on its simplicity, specificity, sensitivity, robustness, cost-effectiveness, and suitability in all circumstances [40]. The MAb based DAS-ELISA developed in this study represents a sustainable and low-cost alternative compared to other methods currently used for X. fastidiosa detection. Like the PCR-based methods, it exhibits high specificity; samples that gave positive results with PCR also reacted by DAS-ELISA MAb2G1/PPD. In contrast to the PCR-based methods, the developed DAS-ELISA can be easily performed in laboratories with a basic structure for microbiology work, even in plant nurseries, and the high performance of these MAbs could also be used for the development of a 'lab-on-a-chip'device such as the one developed for the CoDiRO strain 
by Chiriacòet al. [44], and for other immunological techniques such as tissue print-ELISA, immunofluorescence or lateral flow devices. Especially, tissue print-ELISA is a simple, low-cost, fast, sensitive and accurate way to analyze many samples from nurseries, gardens or large surveys, as clearly showed in other pathosystems [11] and demonstrated in Italy for olive trees testing [20]. The specificity would be guaranteed by the use of MAbs, and also speed, simplicity, low analysis cost, and accuracy, which are characteristics desirable in a diagnostic technique [45].

\section{Conclusions}

Specific MAbs have been developed against X. fastidiosa. They are a versatile tool that can be used in several immunological techniques. These MAbs are promising for a universal utilization, and a further validation with a wider spectrum of X. fastidiosa strains is pending to be completed. The comparison of DAS-ELISA with the selected MAbs with the current gold standard real-time PCR for the analysis of X. fastidiosa in naturally infected plant material revealed that the developed immunological protocol is specific, sensitive and reliable. The obtained Mabs and the ELISA protocol can be used for the large scale surveys of host plants, constituting a very valuable contribution to the management of this harmful pathogen.

Author Contributions: Conceptualization, M.T.G., E.M.-N., and M.M.L.; Methodology, M.T.G., A.S., and J.P.; Validation, M.T.G., A.S., J.P., M.M.L., and E.M.-N.; Formal analysis, M.T.G., E.M.-N., and M.M.L.; Investigation, M.T.G., E.M.-N., and M.M.L.; Resources, M.M.L., M.C., and E.M.-N.; Writing-original draft preparation, M.T.G., M.M.L., and E.M.-N.; Writing—review and editing, M.T.G., M.M.L., and E.M.-N.; Supervision, M.T.G., M.M.L., and E.M.-N.; Project administration, E.M.-N.; Funding acquisition, M.M.L., E.M.-N., and M.C. All authors have read and agreed to the published version of the manuscript.

Funding: This project was funded by the European Union's Horizon 2020 research and innovation program under grant agreements no. 635646 (POnTE, Pest Organisms Threatening Europe) and no. 727987 (XF-ACTORS, Xylella fastidiosa Active Containment Through a Multidisciplinary-Oriented Research Strategy).

Institutional Review Board Statement: The study was conducted according to the guidelines of the Declaration of Helsinki, and approved by INGENASA.

Informed Consent Statement: Not applicable.

Data Availability Statement: Not applicable.

Acknowledgments: Authors thank the Spanish Agriculture Ministry for the support to the Reference Laboratory for Phytopathogenic Bacteria and the Plant Health Service of Comunidad Valenciana for the permission to access the demarcated area of Alicante. They also thank Maria Saponari for providing CoDiRo strain and Mariano Cambra for useful advice and for critical reading of the manuscript.

Conflicts of Interest: The authors declare no conflict of interest.

\section{References}

1. European Union. Commission implementing regulation (EU) 2019/2072 of 28 November 2019 establishing uniform conditions for the implementation of Regulation (EU) 2016/2031 of the European Parliament and the Council, as regards protective measures against pests of plants, and repealing Commission Regulation (EC) No 690/2008 and amending Commission Implementing Regulation (EU) 2018/2019. Off. J. Eur. Union 2019, L319, 1-279.

2. EFSA (European Food Safety Authority). Update of the Xylella spp. host plant database-Systematic literature search up to 30 June 2019. EFSA J. 2020, 18, e06114.

3. Purcell, A.H. Paradigms: Examples from the bacterium Xylellafastidiosa. Ann. Rev. Phytopathol. 2013, 51, 339-356. [CrossRef] [PubMed]

4. Landa, B.B.; Marco-Noales, E.; López, M.M. EnfermedadesCausadaspor la BacteriaXylellafastidiosa; CajamarCaja Rural: Almería, Spain, 2017; 320p.

5. Sicard, A.; Zeilinger, A.R.; Vanhove, M.; Schartel, T.E.; Beal, D.J.; Daugherty, M.P.; Almeida, R.P.P. Xylellafastidiosa: Insights into an emerging plant pathogen. Ann. Rev. Phytopathol. 2018, 56, 181-202. [CrossRef]

6. EPPO. PM 7/24 (4) Xylellafastidiosa. Bull. OEPP/EPPO Bull. 2019, 49, 175-227. [CrossRef] 
7. Landa, B.B.; Castillo, A.I.; Giampetruzzi, A.; Kahn, A.; Román-Écija, M.; Velasco-Amo, M.P.; Navas, J.A.; Marco-Noales, E.; Barbé, S.; Moralejo, E.; et al. Emergence of a plant pathogen in Europe associated with multiple intercontinental introductions. Appl. Environ. Microbiol. 2020, 86, e01521-19. [CrossRef]

8. European Union. Commission Implementing Regulation (EU) 2020/1201 of 14 August 2020 as regards measures to prevent the introduction into and the spread within the Union of Xylellafastidiosa (Wells et al.). Off. J. Eur. Union 2020, L269, 2-39.

9. IPPC-FAO. Diagnostic Protocols for Regulated Pests: Xylellafastidiosa. Int. Stand. Phytosanit. Meas. ISPM 27 2018, DP25, 1-32.

10. EFSA (EuropeanFood Safety Authority); Lázaro, E.; Parnell, S.; Vicent Civera, A.; Schans, J.; Schenk, M.; Schrader, G.; Cortiñas Abrahantes, J.; Zancanaro, G.; Vos, S. Guidelines for statistically sound and risk-based surveys of Xylellafastidiosa. EFSA Support. Publ. 2020, 17, 1873E. [CrossRef]

11. De Boer, S.H.; López, M.M. New grower-friendly methods for plant pathogen monitoring. Ann. Rev. Phytopathol. 2012, 50, 197-218. [CrossRef]

12. Boscia, D.; Myrta, A. Serological detection of viruses included in certification protocols for stone fruits. Options Méditerr. 1998, 19, 171-190.

13. Cambra, M.; Boscia, D.; Gil, M.; Bertolini, E.; Olmos, A. Immunology and immunological assays applied to the detection, diagnosis and control of fruit tree viruses. In Virus and Virus-Like Disease of Pome and Stone Fruits; Hadidi, A., Barba, M., Candresse, T., Jelkmann, W., Eds.; APS Press: St. Paul, MN, USA, 2011; pp. 303-313.

14. López, M.M.; Bertolini, E.; Caruso, P.; Penyalver, R.; Marco-Noales, E.; Gorris, M.T.; Morente, C.; Salcedo, C.; Cambra, M.; Llop, P. Advantages of an integrated approach for diagnosis of quarantine pathogenic bacteria in plant material. Phytopathol. Pol. 2005, $35,49-56$.

15. Sherald, J.L.; Lei, J.D. Evaluation of a rapid ELISA test kit for detection of Xylellafastidiosa in landscaping trees. Plant Dis. 1991, 75, 200-203. [CrossRef]

16. Hartung, J.S.; Beretta, J.; Brlansky, R.H.; Spisso, J.; Lee, R. Citrus variegated chlorosis bacterium: Axenic culture, pathogenicity, and serological relationships with other strains of Xylellafastidiosa. Phytopathology 1994, 84, 591-597. [CrossRef]

17. Lee, R.F.; Beretta, M.J.G.; Derrick, K.S.; Hooker, M.E. Development of a serological assay for citrus variegated chlorosis-A new disease of citrus in Brazil. Proc. Fla. State Hortic. Soc. 1992, 105, 32-35.

18. Chang, C.J.; Garnier, M.; Zreik, L.; Rossetti, V.; Bove, J.M. Culture and serological detection of the xylem-limited bacterium causing citrus variegated chlorosis and its identification as a strain of Xylellafastidiosa. Curr. Microbiol. 1993, 27, 137-142. [CrossRef]

19. Carbajal, D.; Morano, K.A.; Morano, L.D. Indirect immunofluorescence microscopy for direct detection of Xylellafastidiosa in xylem sap. Curr. Microbiol. 2004, 49, 372-375. [CrossRef]

20. Djelouah, K.; Frasheri, D.; Valentini, F.; D’Onghia, A.M.; Digiaro, M. Direct tissue blot immunoassay for detection of Xylellafastidiosa in olive trees. Phytopathol. Mediterr. 2014, 53, 559-564.

21. Harlow, E.; Lane, D. Antibodies: A Laboratory Manual; Cold Spring Harbor Laboratory: New York, NY, USA, 1988; 726p.

22. Koller, G.; Milstein, C. Continuous cultures of fused cells secreting antibody of predefined specificity. Nature 1975, 256, 495-499. [CrossRef]

23. Garnier, M.; Chang, C.J.; Zreik, L.; Rossetti, V.; Bové, J.M. Citrus variegated chlorosis: Serological detection of Xylellafastidiosa, the bacterium associated with the disease. Int. Organ. Citrus Virol.Conf. Proc. (1957-2010) 1993, 12, 301-305.

24. López, M.M.; LLop, P.; Olmos, A.; Marco-Noales, E.; Cambra, M.; Bertolini, E. Are molecular tools solving the challenges posed by detection of plant pathogenic bacteria and viruses? Curr. Issues Mol. Biol. 2008, 11, 13-46. [PubMed]

25. Davis, M.J.; Purcell, A.H.; Thomson, S.V. Isolation media for the Pierce's disease bacterium. Phytopathology 1980, 70, 425-429. [CrossRef]

26. Ridé, M. Bactériesphytopathogèneset maladies bactériennes des végétaux; Ponsot: Paris, France, 1969.

27. Vela, C.; Cambra, M.; Cortés, E.; Moreno, P.; Miguet, J.G.; Pérez de San Román, C.; Sanz, A. Production and characterization of monoclonal antibodies specific for citrus tristeza virus and their use for diagnosis. J. Gen. Virol. 1986, 67, 91-96. [CrossRef]

28. EPPO. PM 7/101 (1): ELISA tests for pathogenic bacteria. Bull. OEPP/EPPO Bull. 2010, 40, 369-372. [CrossRef]

29. European Union. Council Directive of 24 November 1986 on the approximation of laws, regulations and administrative provisions of the Member States regarding the protection of animals used for experimental and other scientific purposes. Off. J. Eur. Union 1986, L358, 1-28.

30. IPPC-FAO. Diagnostic protocols for regulated pests: Citrus tristeza virus. Int. Stand. Phytosanit. Meas. ISPM27 2016, DP15, 1-21.

31. Harper, S.J.; Ward, L.I.; Clover, G.R.G. Development of LAMP and Real-Time PCR methods for the rapid detection of Xylellafastidiosa for quarantine and Field Applications. Phytopathology 2010, 100, 1282-1288. [CrossRef]

32. Francis, M.; Lin, H.; Cabrera-La Rosa, J.; Doddapaneni, H.; Civerolo, E.L. Genome-based PCR for specific and sensitive detection and quantification of Xylella fastidiosa. Eur. J. Plant Pathol. 2006, 115, 203-213. [CrossRef]

33. Olmos, A.; Capote, N.; Bertolini, E.; Cambra, M. Molecular diagnostic methods for plant viruses. In Biotechnology and Plant Disease Management; Punja, Z.K., De Boer, S.K., Sanfaçon, H., Eds.; CABI Press: Oxfordshire, UK, 2007; pp. $227-249$.

34. Cohen, J. A coefficient of agreement for nominal scales. Educ. Psychol. Meas. 1960, 20, 37-46. [CrossRef]

35. Landis, J.R.; Koch, G.G. The measurement of observer agreement for categorical data. Biometrics 1977, 33, 159-174. [CrossRef]

36. McNemar, Q. Note on the sampling error of the difference between correlated proportions or percentages. Psychometrika 1947, 12, 153-157. [CrossRef] [PubMed] 
37. Feinstein, A.R.; Cicchetti, D.V. High agreement but low kappa: I. The problems with two paradoxes. J. Clin. Epidemiol. 1990, 43, 543-549. [CrossRef]

38. Denancé, N.; Legendre, B.; Briand, M.; Olivier, V.; de Boisseson, C.; Poliakoff, F.; Jacques, M.-A. Several subspecies and sequence types are associated with the emergence of Xylellafastidiosa in natural settings in France. Plant Pathol. 2017, 66, 1054-1064. [CrossRef]

39. Minsavage, G.V.; Thompson, C.M.; Hopkins, D.L.; Leite, R.M.V.B.C.; Stall, R.E. Development of a polymerase chain reaction protocol for detection of Xylellafastidiosa in plant tissue. Phytopathology 1994, 84, 456-461. [CrossRef]

40. Waliullah, S.; Hudson, O.; Oliver, J.E.; Brannen, P.M.; Ji, P.; Ali, M.E. Comparative analysis of different molecular and serological methods for detection of Xylellafastidiosa in blueberry. PLoS ONE 2019, 14, e0221903. [CrossRef]

41. Loconsole, G.; Potere, O.; Boscia, D.; Altamura, G.; Djelouah, K.; Elbeaino, T.; Frasheri, D.; Lorusso, D.; Palmisano, F.; Pollastro, P.; et al. Detection of Xylellafastidiosa in olive trees by molecular and serological methods. J. Plant Pathol. 2014, 96, 7-14.

42. Xiao, Y.; Isaacs, S.N. Enzyme-linked immunosorbent assay (ELISA) and blocking with bovine serum albumin (BSA)—Not all BSAs are alike. J. Immunol. Methods 2012, 384, 148-151. [CrossRef]

43. Hilton, A.; Wang, X.; Zhang, M.; Cervantes, K.; French, J.; Randall, J.J.; Bock, C.H.; Grauke, L.J.; Jo, Y. Improved methods for detecting Xylella fastidiosa in pecan and related Carya species. Eur. J. Plant Pathol. 2020, 157, 899-918. [CrossRef]

44. Chiriacò, M.S.; Luvisi, A.; Primiceri, E.; Sabella, E.; De Bellis, L.; Maruccio, G. Development of a lab-on-a-chip method for rapid assay of Xylellafastidiosa subsp. pauca strain CoDiRO. Sci. Rep. 2018, 8, 7376.

45. Baldi, P.; La Porta, N. Xylellafastidiosa: Host range and advances in molecular identification techniques. Front. Plant Sci. 2017, 8, 944. [CrossRef] 